\title{
New Aspects for the Treatment of Cardiac Diseases Based on the Diversity of Functional Controls on Cardiac Muscles: Mitochondrial Ion Channels and Cardioprotection
}

\author{
Hirofumi Nishida ${ }^{1,2, *}$, Toshiaki Sato ${ }^{1}$, Takehiko Ogura ${ }^{1}$, and Haruaki Nakaya ${ }^{1}$ \\ ${ }^{I}$ Department of Pharmacology, ${ }^{2}$ Department of General Surgery, Chiba University Graduate School of Medicine, \\ 1-8-1 Inohana, Chuo-ku, Chiba 260-8670, Japan
}

Received October 16, 2008; Accepted November 5, 2008

\begin{abstract}
Mitochondrial ATP-sensitive $\mathrm{K}^{+}\left(\right.$mitoK $\left._{\mathrm{ATP}}\right)$ and $\mathrm{Ca}^{2+}$-activated $\mathrm{K}^{+}\left(\right.$mitoK $\left._{\mathrm{Ca}}\right)$ channels exist in cardiac myocytes, and they play key roles in cardioprotection. We have recently reported that $\mathrm{K}^{+}$influx through mitoK $\mathrm{K}_{\mathrm{ATP}}$ or mitoK $\mathrm{K}_{\mathrm{Ca}}$ channels occurs independently of each other and confers cardioprotection in a similar manner. Activation of mitoK $\mathrm{K}_{\mathrm{ATP}}$ channel is augmented by protein kinase $\mathrm{C}(\mathrm{PKC})$, whereas mitoK $_{\mathrm{Ca}}$ channel is activated by protein kinase A (PKA). However, phosphatidylinositol 3-kinase $(\mathrm{PI} 3-\mathrm{K})$ is linked to neither mitoK $_{\mathrm{ATP}}$ nor mitoK $_{\mathrm{Ca}}$ channels. We have demonstrated that bioactive substances modulate the opening of mitoK $_{\text {ATP }}$ channels via a PKC-dependent pathway or opening of mitoK $_{\mathrm{Ca}}$ channels via a PKA-dependent pathway and thereby protecting the heart from ischemia/reperfusion injury. Several endogenous substances such as adenosine and bradykinin can reduce infarct size by activation of mitoK $_{\text {ATP }}$ channels in a PKC-dependent manner. Adrenomedullin, a potent vasodilator peptide, potentiates the opening of mitoK $_{\mathrm{Ca}}$ channels by PKA activation. Treatment with adrenomedullin prior to ischemia results in the reduction of infarct size via a PKA-mediated activation of mitoK $_{\mathrm{Ca}}$ channels. Thus, some endogenous substances confer cardioprotection via PKA- or PKC-mediated activation of mitoK $_{\text {ATP }}$ or mitoK $_{\mathrm{Ca}}$ channels.
\end{abstract}

Keywords: cardioprotection, mitochondrial ATP-sensitive $\mathrm{K}^{+}$channel, mitochondrial $\mathrm{Ca}^{2+}$-activated $\mathrm{K}^{+}$channel, protein kinase $\mathrm{A}$, protein kinase $\mathrm{C}$, cardiac disease

\section{Introduction}

Transient episodes of nonlethal ischemia and reperfusion confer profound protection against myocardial injuries in response to a prolonged lethal episode of ischemia-reperfusion ( $\mathrm{I} / \mathrm{R})$, a phenomenon that has been termed ischemic preconditioning (PC) (1). Although researchers have discovered a number of drugs that reduce I/R injury, the study of cardioprotection has been energized by the observation that $\mathrm{PC}$ reduces subsequent lethal ischemia-reperfusion injury $(1,2)$. Investigators have made considerable progress in elucidating the signaling pathways that are activated and required for

*Corresponding author. hinishida@faculty.chiba-u.jp Published online in J-STAGE on March 7, 2009 (in advance) doi: 10.1254 /jphs.08R24FM
PC. Several lines of evidence support the idea that the activation of protein kinase $\mathrm{C}$ (PKC) and/or protein kinase A (PKA) plays an essential role in PC. Furthermore, recent findings have indicated that two kinds of potassium channels exist on the mitochondrial inner membrane, mitochondrial ATP-sensitive $\mathrm{K}^{+}\left(\right.$mitoK $\left._{\text {ATP }}\right)$ channel and $\mathrm{Ca}^{2+}$-activated $\mathrm{K}^{+}$(mitoK $\mathrm{Ca}$ ) channel; and they play critical roles in cardioprotection against I/Rinduced injury $(3-5)$. Activation of PKC, which figures prominently in the signal transduction cascade of PC, increases the open probability of mitoK $\mathrm{K}_{\mathrm{ATP}}$ channels in rabbit hearts (5), whereas activation of PKA potentiates the opening of mitoK $_{\mathrm{Ca}}$ channels as determined in our earlier study (3).

In this manuscript, we briefly review our recent experimental results showing that several bioactive endogenous substances modulate the opening of mitoK $_{\text {ATP }}$ 
channels via a PKC-dependent pathway or opening of mitoK $_{\mathrm{Ca}}$ channels via a PKA-dependent pathway and thereby exert a cardioprotective effect in rabbit hearts. We have discussed the role of mitochondrial potassium channels in the cardioprotection against I/R-induced injury.

\section{Mechanism of cardioprotection by mitochondrial $\mathrm{K}^{+}$ channels}

One of the major physiological features of mitochondria is the generation of a large transmembrane potential across the mitochondrial inner membrane. This is a direct consequence of the biochemical reactions that constitute the respiratory chain. Thus, substrates supplied to mitochondria such as pyruvate, some amino acids, and products of $\beta$-oxidation of fatty acids enter the tricarboxylic acid cycle and maintain the reduced state of the NADH/NAD ${ }^{+}$and $\mathrm{FADH}_{2} / \mathrm{FAD}$ couples. These substances supply electrons to the respiratory chain, which eventually are transferred to oxygen. The process also transfers protons across the mitochondrial inner membrane, generating a proton gradient - a proton motive force that is largely expressed as a membrane potential usually estimated as $180 \mathrm{mV}$ negative to the cytosol. The $\mathrm{Ca}^{2+}$ uptake into mitochondria is driven primarily by this large negative electrical potential of the matrix (6). Therefore, partial depolarization of the mitochondrial membrane through opening of mitochondrial $\mathrm{K}^{+}$channels reduces the driving force for $\mathrm{Ca}^{2+}$ influx, which results in the prevention of mitochondrial $\mathrm{Ca}^{2+}$ overload during ischemia. Ishida et al. have reported that in rat cardiomyocytes, the selective mitoK ATPchannel opener diazoxide depolarizes the mitochondrial membrane and attenuates the mitochondrial $\mathrm{Ca}^{2+}$ overload experimentally evoked by ouabain (7). Ouabain, a $\mathrm{Na}^{+} / \mathrm{K}^{+}$-ATPase inhibitor, impairs $\mathrm{Na}^{+}$extrusion and consequently prevents $\mathrm{Ca}^{2+}$ extrusion via $\mathrm{Na}^{+} / \mathrm{Ca}^{2+}$ exchange. Elevation in cytosolic $\mathrm{Ca}^{2+}$ concentration eventually results in the accumulation of mitochondrial $\mathrm{Ca}^{2+}(8)$. Furthermore, we have recently demonstrated that $\mathrm{K}^{+}$influx via mitochondrial $\mathrm{K}^{+}$channels accelerates electron transfer by the respiratory chain and leads to net oxidation of mitochondria if uncompensated by electron donors and thereby attenuates mitochondrial $\mathrm{Ca}^{2+}$ overload with accompanying depolarization of the mitochondrial membrane $(3,5)$.

\section{MitoK $_{\mathrm{ATP}}$ channel and PKC}

The role of $\mathrm{PKC}$ as a trigger/mediator of the $\mathrm{PC}$ signal is clearly established with recent evidence implicating the role of PKC at the level of the mito- chondria $(9-12)$. Modulation of the mitoK $_{\text {ATP }}$ channel by PKC was revealed by a previous study showing that the PKC-activating phorbol ester PMA potentiates the mitochondrial oxidation induced by diazoxide in rabbit ventricular myocytes with the use of flavoprotein fluorescence method (3). Flavoprotein oxidation was used to determine the pharmacological modulation of mitoK $_{\text {ATP }}$ and mitoK $\mathrm{K}_{\mathrm{Ca}}$ channels in intact cardiac myocytes. Moreover, potentiation of mitoK $_{\text {ATP-channel acti- }}$ vation by adenosine via a PKC-mediated pathway was demonstrated with similar experimental methods (13). Adenosine receptors are not the only endogenous substance that triggers PC. It has been demonstrated that stimulation of various receptors can put the heart into a preconditioned state. These receptors include $\alpha_{1}$-adrenergic (14), bradykinin $\mathrm{B}_{2}(15)$, angiotensin $\mathrm{AT}_{1}$ (16), muscarinic $\mathrm{M}_{2}$ (17), and endothelin $\mathrm{ET}_{\mathrm{A}}$ (18) receptors. Signaling molecules for all of these receptors are released to some degree during PC ischemia and all stimulate Gi- or Gq-linked receptors and ultimately activate PKC (19). Recently, we have found that oxytocin can afford cardioprotection during I/R through the activation of mitoK $\mathrm{K}_{\text {ATP }}$ channels (20). Oxytocin is a small peptide hormone and binds to its membrane receptors on the endometrial cells to increase the activity of phospholipase $\mathrm{C}$, yielding diacylglycerol, a PKC activator. Our preliminary data indicated that oxytocin potentiates the opening of mitoK $\mathrm{K}_{\mathrm{ATP}}$ channels in a PKCdependent manner and has an infarct size-limiting effect in rabbit Langendorff-perfused hearts (20).

\section{MitoK $_{\mathrm{Ca}}$ channel and PKA}

Activation and translocation of PKC are reportedly involved in PC $(21-24)$. There is good evidence that the final mediators of cardioprotection are the ischemiainduced opening of the mitoK $K_{\text {ATP }}$ channels and the production of free radicals. On the other hand, a brief PC ischemia also induces a synchronized increase in the myocardial cyclic AMP (cAMP) level (25). Furthermore, several studies have demonstrated that a brief preischemic exposure to $\beta$-agonists, phosphodiesterase type III inhibitors, and a cell-permeable cAMP analogue, all of which produce rapid activation of PKA, also protect the myocardium in vivo independently of $\operatorname{PKC}(25,26)$. Moreover, our previous study has shown by using the flavoprotein fluorescence method that mitoK $\mathrm{Ca}_{\mathrm{Ca}}$-channel opening can be potentiated by cAMP-dependent protein kinase (3).

To study the PKA-dependent modulation of mitoK $_{\mathrm{Ca}}$ channels, we examined the effects of adrenomedullin (AM) on flavoprotein oxidation in rabbit ventricular cells. AM is a potent vasodilator peptide that was origi- 

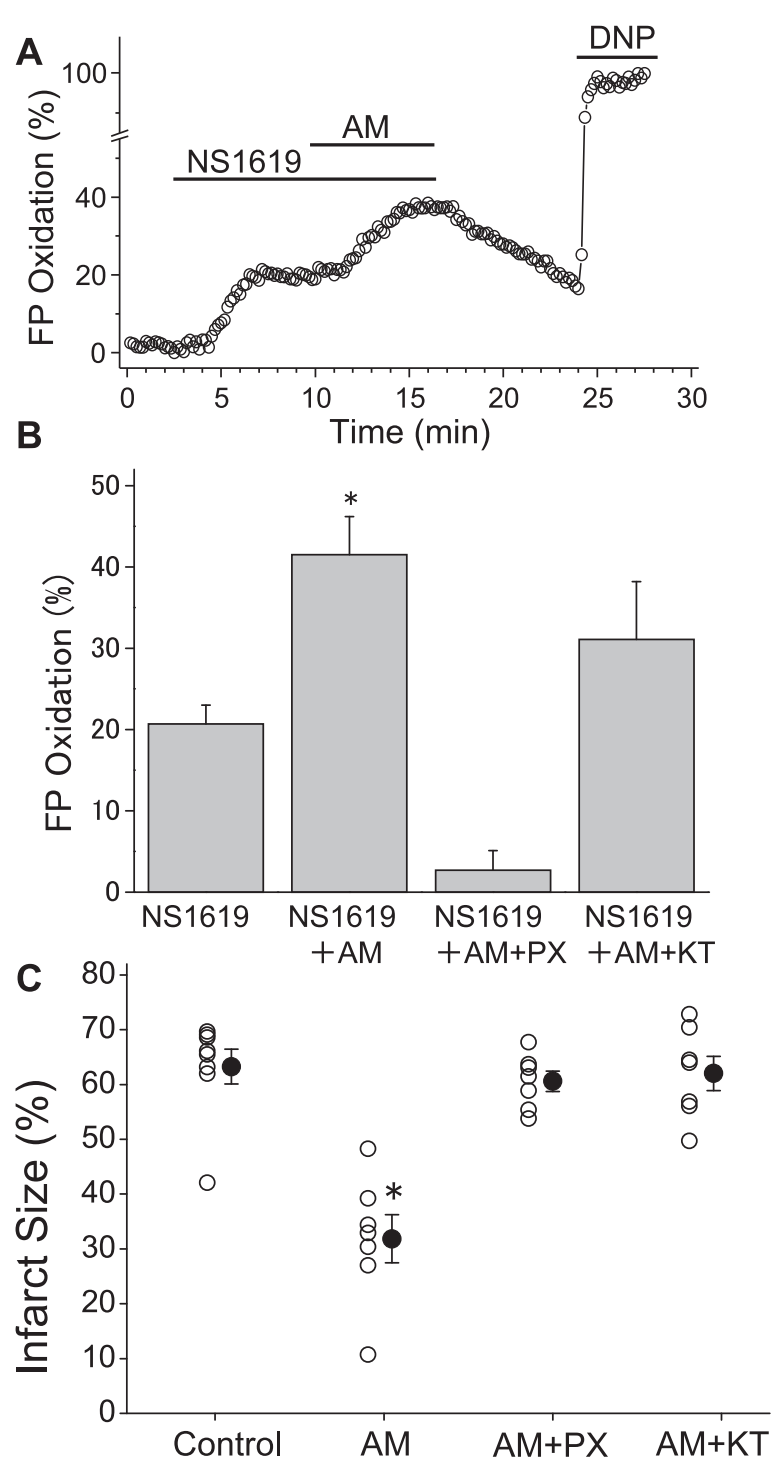

Fig. 1. Effects of adrenomedullin (AM) on flavoprotein (FP) oxidation and myocardial infarct size. A: Representative data showing effects of AM $(10 \mathrm{nM})$ on NS1619 $(30 \mu \mathrm{M})$-induced FP oxidation. Bars indicate periods when the cells were exposed to each drug. FP fluorescence was calibrated by exposing the cells to 2,4-dinitrophenol (DNP, $100 \mu \mathrm{M})$ at the end of experiments. B: Summarized data for percentage of FP oxidation. AM potentiated the NS1619-induced FP oxidation, and paxilline (PX, $2 \mu \mathrm{M})$ completely inhibited the oxidative effect of NS1619 in the presence of AM. In the presence of KT5720 (KT, $200 \mathrm{nM}$ ), AM failed to augment NS1619-induced FP oxidation. Values are expressed as the percent relative to those obtained with DNP. ${ }^{*} P<0.05$ vs. NS1619 alone. C: Summarized effect of AM on infarct size. AM was administered before ischemia. Pretreatment with PX or KT significantly blocked the infarct sizelimiting effect of AM. Each open circle represents the infarct size in an individual heart, and closed circles with error bars are group means \pm S.E.M. ${ }^{*} P<0.01$ vs. control. This modified figure was reproduced with permission from Ref. 28.

nally isolated from human pheochromocytoma tissue by monitoring cAMP levels in platelets (27). Later, the peptide was shown to increase the level of cAMP in a wide variety of cells, including smooth muscle cells, endothelial cells, and cardiac cells. Figure 1A shows the time course of changes in flavoprotein fluorescence in a cell exposed to the mitoK $_{\mathrm{Ca}}$-channel opener NS1619 and AM. Opening of mitoK $\mathrm{Ka}_{\mathrm{Ca}}$ channels by NS1619 oxidized flavoprotein and increased the fluorescence intensity. Subsequent exposure to AM augmented the NS1619-induced flavoprotein oxidation. As summarized in Fig. 1B, NS1619 alone increased flavoprotein oxidation. Although AM significantly augmented the flavoprotein oxidation induced by NS1619, the peptide failed to augment the oxidative effect of NS1619 in the presence of KT5720, a potent inhibitor of PKA. Furthermore, paxilline, a mitoK $\mathrm{Ca}_{\mathrm{a}}$-channel blocker, completely attenuated the oxidative effects of NS1619 in the presence of AM. Then, we examined the effect of AM on infarct size in the isolated perfused rabbit hearts subjected to 30-min global ischemia / 120-min reperfusion. As shown in Fig. 1C, administration of AM to the heart for $10 \mathrm{~min}$ prior to ischemia significantly reduced infarct size compared with the control group. To test whether the infarct size-limiting effect of AM was mediated by PKA-dependent activation of mitoK $\mathrm{Ca}$ channels, we treated the hearts with paxilline or KT5720. Treatment with paxilline blocked the AMinduced reduction in infarct size. Similarly, treatment with KT5720 abolished the infarct size-limiting effect of AM. These results suggest that AM treatment prior to ischemia provides cardioprotection and that the protection is mediated by PKA-dependent activation of mitoK $_{\mathrm{Ca}}$ channels (28).

\section{Mitochondrial $\mathrm{K}^{+}$channels and phosphatidylinositol 3-kinase (PI3-K)}

More recently, the newly developed concept of postconditioning as a way of reducing reperfusion injury has been receiving much attention. The term postconditioning refers to the phenomenon in which brief repetitive episodes of $\mathrm{I} / \mathrm{R}$ at the immediate onset of reperfusion result in a reduction in infarct size (29). Importantly, evidence for the existence of postconditioning has also been obtained in humans (30). Postconditioning-induced protection seems to be mediated via the reperfusion injury salvage kinases (RISK) pathway (31). PI3-K is a component of the RISK pathway, and pharmacological activation of this kinase at reperfusion can mimic postconditioning (31). Accordingly, it would be of great interest to know the link between the activation of PI3-K/Akt and the opening of mitochondrial potassium channels.

To study the link between PI3-K and mitoK ${ }_{\mathrm{Ca}}$ channels, we examined the effects of AM on flavo- 

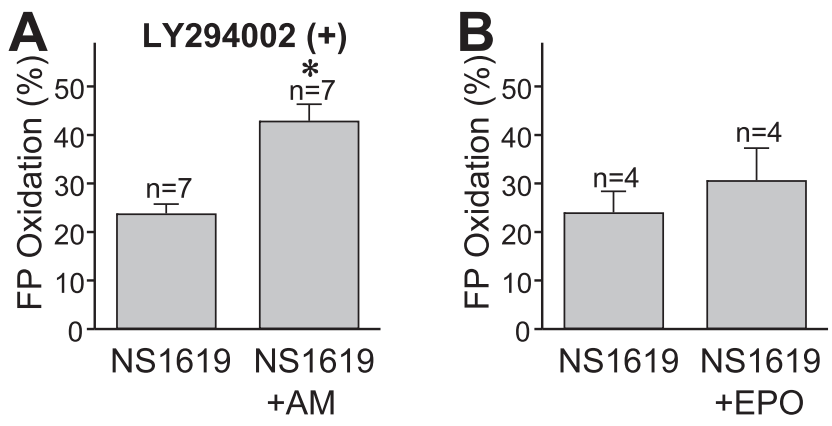

Fig. 2. Summarized effects of PI3-K on mitoK $\mathrm{Ca}_{\mathrm{C}}$ channels. A: AM $(10 \mathrm{nM})$ augmented the oxidative effect of $\operatorname{NS} 1619(30 \mu \mathrm{M})$ even in the presence of LY294002 $(5 \mu \mathrm{M})$. B: Erythropoietin (EPO, 10 units $/ \mathrm{ml}$ ) could not mimic the oxidative effect of AM. Values are expressed as the percent relative to those obtained with DNP. $* P<0.05$ vs. NS1619 alone. This modified figure was reproduced with permission from Ref. 28.

protein oxidation in rabbit ventricular cells again, since Okumura et al. reported that intravenous administration of AM attenuated myocardial $\mathrm{I} / \mathrm{R}$ injury through a PI3-K-dependent pathway (32). As shown in Fig. 2, AM significantly increased the oxidative effect of NS1619 even in the presence of LY294002, a potent inhibitor of PI3-K. Moreover, erythropoietin, a potent activator of PI3-K $(33,34)$, did not augment the NS1619-induced flavoprotein oxidation (28). These results suggest that the mitoK $_{\mathrm{Ca}}$ channel is not regulated by PI3-K. On the other hand, it is unclear whether activation of the PI3-K/Akt pathway modulates the opening of mitoK $\mathrm{K}_{\mathrm{ATP}}$ channels. Interestingly, Lee et al. have reported that BMS-180448, a prototype mitoK $_{\text {ATP-channel opener, }}$ produces a cardioprotective effect without the phosphorylation of Akt (35). Contrary to this report, a recent study by Ahmad et al. has demonstrated that cardioprotection by mitoK $_{\mathrm{ATP}}$-channel activation is dependent on Akt translocation from the cytosol to mitochondria (36). Although the reason for this discrepancy is not clear, our preliminary unpublished data using the flavoprotein fluorescence method suggest that PI3-K activity is independent on mito $_{\mathrm{ATP}}$-channel activation. Further studies are needed to clarify the causal relationship between the PI3-K/Akt pathway and mitoK $\mathrm{K}_{\text {ATP }}$ channels.

Recently, it has been postulated that the activation of the RISK pathway confers its cardioprotection through the inhibition of mitochondrial permeability transition pore (PTP) (37). PTP promotes the release of proapoptotic signaling molecules from the mitochondria and triggers apoptosis (38). Interestingly, the mitoK $\mathrm{ATP}_{\mathrm{A}}$ channel activation, either by intracellular signaling (9) or by mitoK $\mathrm{ATP}_{\mathrm{AT}}$-channel openers, also inhibits the opening of PTP. Taken together, these findings indicate that activation of mitochondrial potassium channels and the PI3-K/Akt pathway independently confer cardioprotection by inhibiting the opening of PTP (Fig. 3).

\section{Functional molecules forming $\operatorname{mitoK}_{\mathrm{ATP}}$ and $\operatorname{mitoK}_{\mathrm{Ca}}$ channels}

The molecular structure of sarcolemmal $\mathrm{K}_{\text {ATP }}$ ( sarcK $_{\text {АTP }}$ ) channels has been clarified by cloning of the inwardly rectifying $\mathrm{K}^{+}$-channel subfamily Kir6.0 [Kir6.1 $(48 \mathrm{kDa})$ and Kir6.2 $(44 \mathrm{kDa})]$ and the receptors for sulfonylureas [SUR1 $(177 \mathrm{kDa})$, SUR2A (74 kDa), and SUR2B $(174 \mathrm{kDa})](39,40)$. From a reconstitution study, cardiac sarcK $\mathrm{K}_{\mathrm{ATP}}$ channels have been suggested to comprise SUR2A and Kir6.2 (41). Our functional study using Kir6.2-deficient mice has provided direct evidence that Kir6.2 forms the pore region of cardiac sarcK $_{\mathrm{ATP}}$ channels (42). On the other hand, molecular identification of mitoK $\mathrm{K}_{\text {ATP }}$ channel has not been made yet.

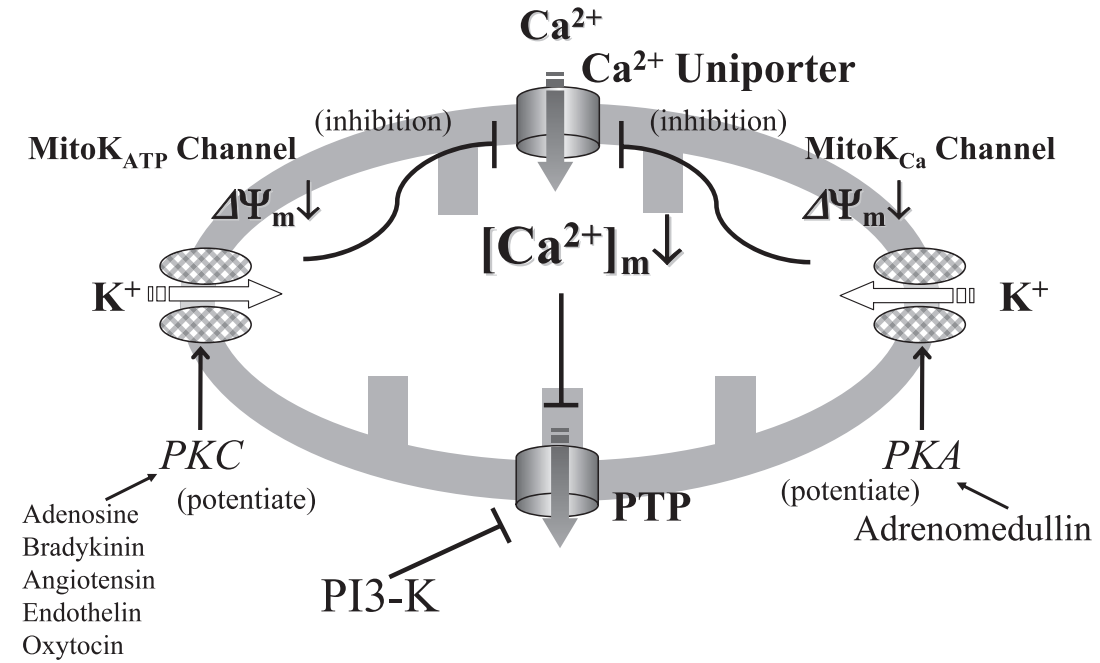

Fig. 3. Schematic representation of the mechanism of protection mediated by mitoK $_{\mathrm{ATP}}$ and mitoK $_{\mathrm{Ca}}$ channels. PKA potentiates $\operatorname{mitoK}_{\mathrm{Ca}}-$ channel activation, whereas PKC potentiates mitoK $_{\text {ATp-channel activation. Opening of } \text { mitoK }_{\mathrm{Ca}}}$ channels and mitoK $\mathrm{K}_{\text {ATP }}$ channels depolarizes $\Delta \Psi_{\mathrm{m}}$, which reduces the driving force for $\mathrm{Ca}^{2+}$ influx, thereby attenuating the mitochondrial $\mathrm{Ca}^{2+}$ overload. Consequently, prevention of matrix $\mathrm{Ca}^{2+}$ overload inhibits the opening of mitochondrial permeability transition pore (PTP) and protects against heart cell death by an antiapoptic mechanism. It has been demonstrated that the PI3-K /Akt pathway is independently involved in cardioprotection through the direct inhibition of PTP. 
However, there are many lines of evidence linking the opening of the mitoK $\mathrm{K}_{\text {ATP }}$ channel to protection against I/R injury or apoptosis. Although the molecular identity of the mitoK ${ }_{\text {ATP }}$ channel remains unclear, experiments using dominant negative gene transfer have indicated that neither Kir6.1 nor Kir6.2 is a functionally important part of the mitoK ${ }_{\text {ATP }}$ channel in native heart cells (43). In addition, the mitoK $\mathrm{ATP}_{\mathrm{AT}}$-channel function, evaluated by flavoprotein oxidation, was preserved in cardiomyocytes of either Kir6.2-deficient (44) or Kir6.1-deficient mice (45). However, $\mathrm{K}^{+}$uniport activity has been observed when purified mitochondrial proteins in the molecular weight range of $50-60 \mathrm{kDa}$ have been reconstituted into proteoliposomes, $(46,47)$, and a $54-\mathrm{kDa}$ protein was tentatively identified as a component of mitoK $_{\text {ATP }}(48)$. The existence of SUR proteins in heart mitochondria is still controversial $(49,50)$, whilst a protein of about $28 \mathrm{kDa}$ was labeled by [ $\left.{ }^{125} \mathrm{I}\right]$-glibencamide (51). Recently, Ardehali et al. have reported that the mitoK $\mathrm{K}_{\text {ATP }}$ channel is potentially composed of four mitochondrial proteins (mitochondrial ATP-binding cassette protein 1, phosphate carrier, adenine nucleotide translocator, and ATP synthase) and succinate dehydrogenase; and thus it is a multiprotein complex (52).

Large-conductance $\mathrm{Ca}^{2+}$-activated $\mathrm{K}^{+}(\mathrm{BK})$ channels are ubiquitously expressed in both excitable and nonexcitable cells and contribute to diverse physiological processes. BK channels are composed of tetrameric sets consisting of a pore-forming $\alpha$-subunit and an auxiliary subunit, $\beta$-subunit (53). In contrast to $\mathrm{K}_{\mathrm{ATP}}$ channels, the BK channels are not functionally expressed in the sarcolemma of cardiomyocytes. However, a study from O'Rourke's laboratory (54) has suggested that a BK channel is expressed in the mitochondrial inner membrane of ventricular myocytes ( mitoK $_{\mathrm{Ca}}$ channel). Studies of the pharmacological and biochemical profiles have suggested that mitoK $\mathrm{Ca}$ channels belong to the Slo-1 family $(54,55)$; however, the molecular components of mitoK $_{\mathrm{Ca}}$ channels also have not been identified as mitoK $_{\text {ATP }}$ channels. Recently Ohya et al. have demonstrated that $\mathrm{BK}$ channel $\beta 1$-subunit transcripts are expressed in mammalian cardiac mitochondria (56). Identification of functional molecules forming mitochondrial $\mathrm{K}^{+}$channels may enable considerable progress in the search for a new type of cardioprotective drugs.

\section{Concluding remarks}

The mitochondrial $\mathrm{K}_{\mathrm{ATP}}$ and $\mathrm{K}_{\mathrm{Ca}}$ channels play an important role in cardioprotection. This review has focused on the compelling evidence that they can act as signal transduction elements to trigger as well as mediate the PC state. In addition, the IONA study (57) has demonstrated a significant improvement in outcome due to a reduction in major coronary events by antianginal therapy with nicorandil, a mitoK $\mathrm{ATP}_{\mathrm{TP}}$-channel opener, in patients with stable angina. This outcome can strongly support the applicability of this class of drugs to clinical settings.

Despite unanswered questions and remaining ambiguities, many studies in this field consistently support the existence of potassium channels in the mitochondria, activation of which leads to protection against cell death and apoptosis. The pharmacological and structural profiles of these channels may be of paramount importance, and activators of these channels may provide new therapeutic strategies for ischemic heart disease.

\section{Acknowledgments}

The authors gratefully acknowledge the assistance of $\mathrm{M}$ Tamagawa and Y. Reien, who provided excellent technical support, and I. Sakashita, who provided superb secretarial support. This study was supported in part by Grants-in-Aid for Scientific Research from the Japan Society for the Promotion of Science, Mitsui Life Social Welfare Foundation, and K. Watanabe Research Foundation.

\section{References}

1 Murry CE, Jennings RB, Reimer KA. Preconditioning with ischemia: a delay of lethal cell injury in ischemic myocardium. Circulation. 1986;74:1124-1136.

2 Murry CE, Richard VJ, Reimer KA, Jennings RB. Ischemic preconditioning slows energy metabolism and delays ultrastructural damage during a sustained ischemic episode. Circ Res. 1990;66:913-931.

3 Sato T, Saito T, Saegusa N, Nakaya H. Mitochondrial $\mathrm{Ca}^{2+}$ activated $\mathrm{K}^{+}$channels in cardiac myocytes: a mechanism of the cardioprotective effect and modulation by protein kinase $\mathrm{A}$. Circulation. 2005;111:198-203.

4 Liu Y, Sato T, O'Rourke B, Marban E. Mitochondrial ATPdependent potassium channels: novel effectors of cardioprotection? Circulation. 1998;97:2463-2469.

5 Sato T, O'Rourke B, Marban E. Modulation of mitochondrial ATP-dependent $\mathrm{K}^{+}$channels by protein kinase C. Circ Res. 1998;83:110-114.

6 Gunter TE, Pfeiffer DR. Mechanisms by which mitochondria transport calcium. Am J Physiol. 1990;258:C755-C786.

7 Ishida H, Hirota Y, Genka C, Nakazawa H, Nakaya H, Sato T. Opening of mitochondrial $\mathrm{K}_{\text {ATP }}$ channels attenuates the ouabaininduced calcium overload in mitochondria. Circ Res. 2001;89: 856-858.

8 Duchen MR. Contributions of mitochondria to animal physiology: from homeostatic sensor to calcium signaling and cell death. J Physiol. 1999;516:1-17.

9 Costa AD, Garlid KD, West IC, Lincoln TM, Downey JM, Cohen MV, et al. Protein kinase G transmits the cardioprotective signal from cytosol to mitochondria. Circ Res. 2005;97:329336.

10 Andrukhiv A, Costa AD, West IC, Garlid KD. Opening mitoK ATP 
increases superoxide generation from complex I of the electron transport chain. Am J Physiol Heart Circ Physiol. 2006;291: H2067-H2074.

11 Costa AD, Jakob R, Costa CL, Andrukhiv K, West IC, Garlid $\mathrm{KD}$. The mechanism by which the mitochondrial ATP-sensitive $\mathrm{K}^{+}$channel opening and $\mathrm{H}_{2} \mathrm{O}_{2}$ inhibit the mitochondrial permeability transition. J Biol Chem. 2006;281:20801-20808.

12 Jaburek M, Costa AD, Burton JR, Costa CL, Garlid KD. Mitochondrial PKC epsilon and mitochondrial ATP-sensitive $\mathrm{K}^{+}$channel copurify and coreconstitute to form a functioning signaling module in proteoliposomes. Circ Res. 2006;99:878883.

13 Sato T, Sasaki N, O’Rourke B, Marbán E. Adenosine primes the opening of mitochondrial ATP-sensitive potassium channels: a key step in ischemic preconditioning? Circulation. 2000;102: 800-805.

14 Tsuchida A, Liu Y, Liu GS, Cohen MV, Downey JM. alpha1Adrenergic agonists precondition rabbit ischemic myocardium independent of adenosine by direct activation of protein kinase C. Circ Res. 1994;75:576-585.

15 Goto M, Liu Y, Yang X-M, Ardell JL, Cohen MV, Downey JM. Role of bradykinin in protection of ischemic preconditioning in rabbit hearts. Circ Res. 1995;77:611-621.

16 Liu Y, Tsuchida A, Cohen MV, Downey JM. Pretreatment with angiotensin II activates protein kinase $\mathrm{C}$ and limits myocardial infarction in isolated rabbit hearts. J Mol Cell Cardiol. 1995; 27:883-892.

17 Yao Z, Gross GJ. Acetylcholine mimics ischemic preconditioning via a glibenclamide-sensitive mechanism in dogs. Am J Physiol. 1993;264:H2221-H2225.

18 Bugge E, Ytrehus K. Endothelin-1 can reduce infarct size through protein kinase $\mathrm{C}$ and $\mathrm{K}_{\text {ATP }}$ channels in the isolated rat heart. Cardiovasc Res. 1996;32:920-929.

19 Yellon DM, Downey JM. Preconditioning the myocardium: from cellular physiology to clinical cardiology. Physiol Rev. 2003;83:1113-1151.

20 Nishida H, Sato T, Fukasawa M, Miyazaki M, Nakaya H. Oxytocin potentiates the opening of mitochondrial ATPsensitive $\mathrm{K}^{+}$channels and reduces infarct size in rabbit hearts. J Pharamacol Sci. 2007;103 Suppl I:102P.

21 Brown GC. Regulation of mitochondrial respiration by nitric oxide inhibition of cytochrome c oxidase. Biochim Biophys Acta. 2001;1504:46-57.

22 Hu K, Duan D, Li GR, Nattel S. Protein kinase C activates ATPsensitive $\mathrm{K}^{+}$current in human and rabbit ventricular myocytes. Circ Res. 1996;78:492-498.

23 Liu Y, Ytrehus K, Downey JM. Evidence that translocation of protein kinase $\mathrm{C}$ is a key event during ischemic preconditioning of rabbit myocardium. J Mol Cell Cardiol. 1994;26:661-668.

24 Meldrum DR, Cleveland JC Jr, Mitchell MB, Sheridan BC, Gamboni-Robertson F, Harken AH, et al. Protein kinase C mediates $\mathrm{Ca}^{2+}$-induced cardioadaptation to ischemia-reperfusion injury. Am J Physiol Regul Integr Comp Physiol. 1996;271: R718-R726.

25 Lochner A, Genade S, Tromp E, Podzuweit T, Moolman JA. Ischemic preconditioning and the beta-adrenergic signal transduction pathway. Circulation. 1999;100:958-966.

26 Fukasawa M, Nishida H, Sato T, Miyazaki M, Nakaya H. Cilostazol, a phosphodiesterase type 3 inhibitor, reduces infarct size via activation of mitochondrial $\mathrm{Ca}^{2+}$-activated $\mathrm{K}^{+}$channels in rabbit hearts. J Pharmacol Exp Ther. 2008;326:100-104.

27 Kitamura K, Kangawa K, Kawamoto M, Ichiki Y, Nakamura S, Matsuo $\mathrm{H}$, et al. Adrenomedullin: a novel hypotensive peptide isolated from human pheochromocytoma. Biochem Biophys Res Commun. 1993;192:553-560.

28 Nishida H, Sato T, Miyazaki M, Nakaya H. Infarct size limitation by adrenomedullin: protein kinase $\mathrm{A}$ but not PI3-kinase is linked to mitochondrial $\mathrm{K}_{\mathrm{Ca}}$ channels. Cardiovasc Res. 2008;77: 398-405.

29 Zhao ZQ, Vinten-Johansen J. Postconditioning: reduction of reperfusion-induced injury. Cardiovasc Res. 2006;70:200-211.

30 Staat P, Rioufol G, Piot C, Cottin Y, Cung TT, L'Huillier I, et al. Postconditioning the human heart. Circulation. 2005;112:21432148.

31 Yellon DM, Hausenloy DJ. Myocardial reperfusion injury. N Engl J Med 2007;357:1121-1135.

32 Okumura H, Nagaya N, Itoh T, Okano I, Hino J, Mori K, et al. Adrenomedullin infusion attenuates myocardial ischemia/reperfusion injury through the phosphatidylinositol 3-kinase/Aktdependent pathway. Circulation. 2004;109:242-248.

33 Tramontano AF, Muniyappa R, Black AD, Blendea MC, Cohen I, Deng L, et al. Erythropoietin protects cardiac myocytes from hypoxia-induced apoptosis through an Akt-dependent pathway. Biochem Biophys Res Commun. 2003;308:990-994.

34 Cai Z, Semenza GL. Phosphatidylinositol-3-kinase signaling is required for erythropoietin-mediated acute protection against myocardial ischemia/reperfusion injury. Circulation. 2004;109: 2050-2053.

35 Lee JH, Jung IS, Lee SH, Yang MK, Hwang JH, Lee HD, et al. Cardioprotective effects of BMS-180448, a prototype mitoK $\mathrm{K}_{\text {ATP }}$ channel opener, and the role of salvage kinases, in the rat model of global ischemia and reperfusion heart injury. Arch Pharm Res. 2007;30:634-640.

36 Ahmad N, Wang Y, Haider KH, Wang B, Pasha Z, Uzun O, et al. Cardiac protection by mitoK $\mathrm{K}_{\mathrm{ATP}}$ channels is dependent on Akt translocation from cytosol to mitochondria during late preconditioning. Am J Physiol Heart Circ Physiol. 2006;290:H2402H2408.

37 Hausenloy DJ, Yellon DM. New directions for protecting the heart against ischemia-reperfusion injury: targeting the Reperfusion Injury Salvage Kinase (RISK)-pathway. Cardiovasc Res. 2004;61:448-460.

38 Weiss JN, Korge P, Honda HM, Ping P. Role of the mitochondrial permeability transition in myocardial disease. Circ Res. 2003;93:292-301.

39 Inagaki N, Gonoi T, Clement JP 4th, Namba N, Inazawa J, Gonzalez G, et al. Reconstitution of IKATP: an inward rectifier subunit plus the sulfonylurea receptor. Science. 1995;270:11661170 .

40 Seino S. ATP-sensitive potassium channels: a model of heteromultimeric potassium channel/receptor assemblies. Annu Rev Physiol. 1999;61:337-362.

41 Inagaki N, Gonoi T, Clement JP, Wang CZ, Aguilar-Bryan L, Bryan J, et al. A family of sulfonylurea receptors determines the pharmacological properties of ATP-sensitive $\mathrm{K}^{+}$channels. Neuron. 1996;16:1011-1017.

42 Suzuki M, Li RA, Miki T, Uemura H, Sakamoto N, OhmotoSekine Y, et al. Functional roles of cardiac and vascular ATPsensitive potassium channels clarified by Kir6.2-knockout mice. Circ Res. 2001;88:570-577. 
43 Seharaseyon J, Ohler A, Sasaki N, Fraser H, Sato T, Johns DC, et al. Molecular composition of mitochondrial ATP-sensitive potassium channels probed by viral gene transfer. J Mol Cell Cardiol. 2000;32:1923-1930.

44 Suzuki M, Sasaki N, Miki T, Sakamoto N, Ohmoto-Sekine Y, Tamagawa $M$, et al. Role of sarcolemmal $K_{\text {ATP }}$ channels in cardioprotection against ischemia/reperfusion injury in mice. J Clin Invest. 2002;109:509-516.

45 Miki T, Suzuki M, Shibasaki T, Uemura H, Sato T, Yamaguchi $\mathrm{K}$, et al. Mouse model of Prinzmetal angina by disruption of the inward rectifier Kir6.1. Nat Med. 2002;8:466-472.

46 Diwan JJ, Haley T, Sanadi DR. Reconstitution of transmembrane $\mathrm{K}^{+}$transport with a 53 kilodalton mitochondrial protein. Biochem Biophys Res Commun. 1988;153:224-230.

47 Paliwal R, Costa G, Diwan JJ. Purification and patch clamp analysis of a $40-\mathrm{pS}$ channel from rat liver mitochondria. Biochemistry. 1992;31:2223-2229.

48 Paucek P, Mironova G, Mahdi F, Beavis AD, Woldegiorgis G, Garlid KD. Reconstitution and partial purification of the glibenclamide-sensitive, ATP-dependent $\mathrm{K}^{+}$channel from rat liver and beef heart mitochondria. J Biol Chem. 1992;267: 26062-26069.

49 Szewczyk A, Skalska J, Glab M, Kulawiak B, Malinska D, Koszela-Piotrowska I, et al. Mitochondrial potassium channels: from pharmacology to function. Biochim Biophys Acta. 2006; 1757:715-720.

50 Lacza Z, Snipes JA, Miller AW, Szabo C, Grover G, Busija DW. Heart mitochondria contain functional ATP-dependent $\mathrm{K}^{+}$ channels. J Mol Cell Cardiol. 2003;35:1339-1347.
51 Singh H, Hudman D, Lawrence CL, Rainbow RD, Lodwick D, Norman RI. Distribution of Kir6.0 and SUR2 ATP-sensitive potassium channel subunits in isolated ventricular myocytes. J Mol Cell Cardiol. 2003;35:445-459.

52 Ardehali H, Chen Z, Ko Y, Mejia-Alvarez R, Marban E. Multiprotein complex containing succinate dehydrogenase confers mitochondrial ATP-sensitive $\mathrm{K}^{+}$channel activity. Proc Natl Acad Sci U S A. 2004;101:11880-11885.

53 Wallner M, Meera P, Toro L. Determinant for beta-subunit regulation in high-conductance voltage-activated and $\mathrm{Ca}^{2+}$. sensitive $\mathrm{K}^{+}$channels: an additional transmembrane region at the N terminus. Proc Natl Acad Sci U S A. 1996;93:14922-14927.

54 Xu WH, Liu YG, Wang S, McDonald T, VanEyk JE, Sidor A, et al. Cytoprotective role of $\mathrm{Ca}^{2+}$-activated $\mathrm{K}^{+}$channels in the cardiac inner mitochondrial membrane. Science. 2002;298: 1029-1033.

55 Siemen D, Loupatatzis C, Borecky J, Gulbins E, Lang F. Ca ${ }^{2+}$ activated $\mathrm{K}^{+}$channel of the BK-type in the inner mitochondrial membrane of a human glioma cell line. Biochem Biophys Res Commun. 1999;257:549-554.

56 Ohya S, Kuwata Y, Sakamoto K, Muraki K, Imaizumi Y. Cardioprotective effects of estradiol include the activation of large-conductance $\mathrm{Ca}^{2+}$-activated $\mathrm{K}^{+}$channels in cardiac mitochondria. Am J Physiol Heart Circ Physiol. 2005;289: H1635-H1642.

57 The IONA Study Group. Effect of nicorandil on major events in patients with stable angina: the impact of nicorandil in angina (IONA) randomised trial. Lancet. 2002;359:1269-1275. 